\title{
Rational and Sustainable Water Resource Management in the Ptolemais Lignite Basin Using Remotely Sensed Data ${ }^{\dagger}$
}

\author{
Georgios Louloudis, Christos Roumpos*D, Eleni Mertiri, Georgios Kasfikis and Francis Pavloudakis
}

check for updates

Citation: Louloudis, G.; Roumpos,

C.; Mertiri, E.; Kasfikis, G.;

Pavloudakis, F. Rational and Sustainable Water Resource Management in the Ptolemais Lignite Basin Using Remotely Sensed

Data. Mater. Proc. 2021, 5, 44. https:// doi.org/10.3390/materproc2021005044

Academic Editor:

Konstantinos Simeonidis

Published: 2 December 2021

Publisher's Note: MDPI stays neutral with regard to jurisdictional claims in published maps and institutional affiliations.

Copyright: (c) 2021 by the authors. Licensee MDPI, Basel, Switzerland. This article is an open access article distributed under the terms and conditions of the Creative Commons Attribution (CC BY) license (https:// creativecommons.org/licenses/by/ $4.0 /)$.
Public Power Corporation of Greece, Department of Mining Engineering, 10432 Athens, Greece; g.louloudis@dei.gr (G.L.); elmertiri@gmail.com (E.M.); g.kasfikis@dei.gr (G.K.); f.pavloudakis@dei.gr (F.P.)

* Correspondence: c.roumpos@dei.gr; Tel.: +30-697-979-9291

+ Presented at International Conference on Raw Materials and Circular Economy, Athens, Greece, 5-9 September 2021.

\begin{abstract}
Future investment feasibility studies concerning post-mining repurposing utilities and economic transitions should focus on regional water resource management and the hydraulic protection of any utilities. Satellite images in different bands and Digital Elevation Models (DEM) of the Ptolemais basin were processed, leading to a more accurate estimation of the runoff ratio and percolation ratio. Furthermore, the saturated and unsaturated areas were delineated, leading to the recognition of potential artificial ground water recharge zones and zones where appropriate hydraulic protection measures are necessary.
\end{abstract}

Keywords: Topographic Wetness Index (TWI); Power Stream Index (SI); slope length and steepness factor ( $L S$-factor); Normalized Difference Water Index (NDWI); Modified Normalized Difference Water Index (MNDWI); Normalized Difference Vegetation Index (NDVI)

\section{Introduction}

Greece is committed to the European Commission's long-term strategic vision to achieve technological neutrality to $\mathrm{CO}_{2}$ emissions by using renewable energies [1,2]. In the era of the early and rapid closure of mines, the Public Power Corporation (PPC) of Greece is engaged in planning for the transition away from coal and the adoption of Renewable Energy Source (RES) technology [3]. As a result, multi-level planning is critical to design and implement effective strategies, explore repurposing options, and make decisions about a post-mining future and economic transitions. Planning should include (a) water management issues, examining the new demands of water, (b) the spatiotemporal development of water inside the mined-out pits, including the effect of the planned end uses, (c) the hydraulic protection of the new RES and other projects (e.g., the application of pumped hydro storage (PHS) technology in the abandoned mines), and (e) the needs in water for successful end uses.

During the operation period in lignite mines, dewatering measures were adopted (dewatering wells, pumping stations) to lower the groundwater table by pumping water from the aquifer and abstracting rainwater accumulated in the pits. However, RES and other projects in the mine complex area will demand new water management strategies.

The main objective of this research is to provide a methodology to identify areas where the application of hydraulic protection is imperative, in order to estimate the design water inflow risk and the feasibility of hydraulic protection works via remotely sensed data from satellites (satellite images, DEM, etc.).

\section{Materials and Methods \\ 2.1. Research Area-Hydrogeological Conditions}

The research area refers to the South Ptolemais lignite basin (Western Macedonia, Greece), where open-cast mining [4] was developed (Figure 1). The formations encountered 
in the Ptolemais basin include Tertiary and Quaternary sediments up to $1000 \mathrm{~m}$ thick, overlying Paleozoic schists, granites and ophiolites [3,5]. Furthermore, the Pelagonian Structural Zone-consisting of Mesozoic dolomitic limestones, volcanic sediments and flysch-overlays the Paleozoic formations. The encountered sediments consist of sand, clay, marls, conglomerates, and lignite on the surface.

Mountain stream networks consist of bedrock and mainly consolidated sediment channels, where the water flows downhill and eventually into the Soulou River. The waterbearing horizons that lie above the impermeable lignite strata form a unique hydraulically connected network that behaves as one aquifer [6]. The surface runoff of the mountainous surroundings to the hydrogeological basin has been proved insignificant according to Papakonstantinou's [7] measurements of Vermion stream discharge. However, a considerable volume of hydraulic studies conducted by the PPC [8] has considered high flooding rates to define the necessary hydraulic protection measures. Concerning the contradictory results of different hydrogeological or topographical approaches, an interesting research question concerns the investigation of the flooding hazards based on remotely sensed data.

The mean temperature and rainfall calculated for the last 14 years are $14.22^{\circ} \mathrm{C}$ and $512.29 \mathrm{~mm}$, with standard deviation values of $0.45^{\circ} \mathrm{C}$ and $129.51 \mathrm{~mm}$ for the Ptolemaida weather stations, respectively. According to the Köppen climate classification, the climate is characterised as moist with mild winters, wet for all seasons, with a long and hot summer.
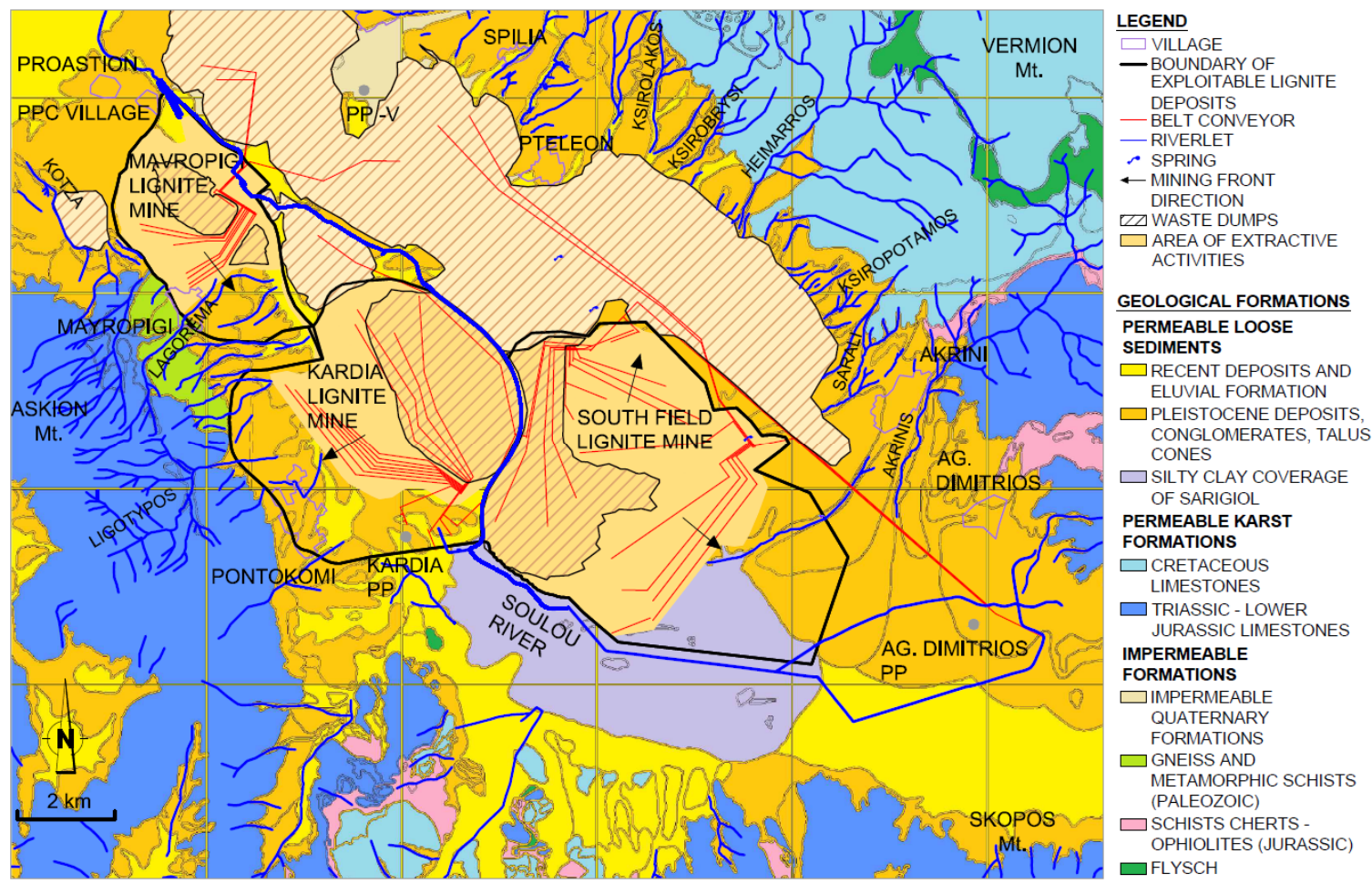

Figure 1. Geological and hydro-lithological map in the Ptolemais basin [8].

\subsection{Methods}

A wide range of techniques were used, and satellite images in different bands and Digital Elevation Models (DEM) of the Ptolemais basin were processed and analysed. These include the use of topography indices and satellite image processing indices.

Topography has a major impact on the catchment geomorphology and hydrology. DEMs were processed, and the spatial distribution of the topographic attributes was used to describe the spatial soil moisture patterns. The main topographic indices that can be deduced by processing DEMs are the Topographic Wetness Index (TWI) [9,10], 
Power Stream Index (SI) [10] and Slope length and steepness factor (LS-factor) [11,12]. Equations (1)-(3) were applied to calculate the topographic indices:

$$
\begin{gathered}
S I=A s \cdot \tan b, \\
T W I=\ln (a / \tan b), \\
L S=(A s / 22.13)^{0.6}(\sin b / 0.0896)^{1.3},
\end{gathered}
$$

where $A s$ is the specific catchment's area, $b$ is the local slope gradient, and $a$ is the total cumulative upslope area drained through a point per unit contour length.

Satellite image processing methods can be a useful tool to map water features and monitor land cover. Landsat spectral bands with a high spatial resolution were used to generate output layers and calculate the spectral indices, as a product of the bands' Top of the Atmosphere (TOA) reflectance value. Landsat- 5 and Landsat- 8 satellite images were used in the analyses performed. The main indices that can be deduced by processing satellite images are the Normalised Difference Vegetation Index (NDVI) [13,14], Normalized Difference Water Index (NDWI) [14-17], and Modified Normalized Difference Water Index $(M N D W I)[14,18,19]$. Equations (4)-(6) were applied to calculate the spectral indices:

$$
\begin{gathered}
N D V I=(N I R-R E D) /(N I R+R E D), \\
N D W I=(G R E E N-N I R) /(G R E E N+N I R), \\
M N D W I=(G R E E N-M I R) /(G R E E N+M I R),
\end{gathered}
$$

where NIR is the TOA reflectance value of the near-infrared band, RED is the TOA reflectance value of the red band, GREEN is the TOA reflectance value of the green band, and MIR is a middle (shortwave) infrared band.

Regarding the satellite images, these were acquired in October 2016, in December 2016, in October 2018 and in October 2019, and were compared in order to obtain more accurate information. More specifically, the Sentinel-2 Satellite Imagery was used to calculate NDWI and MNDWI, while for the NDVI analysis, two satellite images on 26 July 2007 (Landsat-5) and on 15 July 2018 (Landsat-8) were used.

Maps were produced for each of the indices, and also for all of the satellite images mentioned above. Through the spatial distribution computation of the indices, a better presentation of the hydrological status was achieved. Furthermore, the water content origin and flow in the unsaturated and saturated zones were clearly delineated.

Finally, the runoff coefficient $(\mathrm{Cr})[20,21]$ was estimated using Equations (7) and (8):

$$
\begin{gathered}
C r=\left(P_{v o l}-0.2\left(\left(\frac{25400}{C N}\right)-254\right)\right)^{2} / P_{v o l}\left(P_{v o l}+0.8\left(\left(\frac{25400}{C N}\right)-254\right)\right), \\
P_{v o l}=I_{T c} T_{C},
\end{gathered}
$$

where $P_{\text {vol }}$ is the volume of rainfall in $\mathrm{mm}, \mathrm{CN}$ is the curve number, $I_{T c}$ is the mean rainfall intensity for the $T_{C}(\mathrm{~mm} / \mathrm{h})$, and $T_{C}$ is the time of the concentration (h), which is usually described by the Giandotti equation [22].

\section{Results and Discussion}

The study area is dominated by small bodies of water and streams of low capacity (Figure 1). These water bodies were identified in the maps produced using the topographic and spectral indices. Regarding the appearance and location of these water bodies, the results are consistent with the former studies and topographical mapping conducted by the Hellenic Military Geographical Service. Indicative maps of TWI and PI are presented in Figure 2, and maps of NDWI are presented in Figure 3.

The drainage channels developed through the TWI index are identical to the hydrographic network recorded by geologists through field research (Figure 1). The saturated 
areas were identified through the spatial distribution of the SI, TWI and LS indices, where the relative wetness in the catchment areas is predicted. From the evaluation, it is evident that the potential for the streams to be hydrologically active is higher for Vermion streams compared to Askion streams. Soulou river and its channels appear to be more active, presenting perennial flow. Furthermore, potential water bodies with an intermittent or ephemeral flow were identified at the N-E part of the South Field's external waste dump margins and the internal waste deposition at the west margins inside Kardia mine. A significant flow velocity was evident only in the consolidated rocky mountains (Figure 2b). The same applies for the spatial distribution of the $L S$ values, indicating that water discharge is apparent only on the Vermion, Askion and Skopos mountains, while the intensity of weathering is more evident on Vermion Mountain.

The water-stressed conditions were subsequently evaluated via spectral indices. The NDWI spatial extent (Figure 3) shows water accumulation in specific areas, i.e., the old Sarigiol swamp (the area south of the exploitable lignite deposits), the external waste dump (north of the exploitable lignite deposits) and the mine sumps. The most striking observation to emerge from the data analysis was the different appearance of the riverlets between Askion Mountain, Vermion Mountain and Sarigiol basin (Skopos Mountain). The results indicate that the streams of Vermion Mountain can be characterised as wet areas over all of winter, despite their intermittent discharge.

Finally, by processing the CN European raster file [23], the runoff coefficient was calculated (Figure 4). Regarding excavations and inside dumping, the present study showed that the runoff coefficient is much higher (20-30\%) than that outside the pit perimeter, where the runoff coefficient hardly exceeds $5 \%$. Only south of South Lignite Field does the runoff coefficient reach $10 \%$. However, the surface flow direction is the opposite of the direction towards the exploitation front, implying that hydraulic protection measures are unnecessary.

Furthermore, the results strongly imply that all of the streams coming from Vermion Mountain have a low runoff coefficient (less than 10\%) in the region of the talus cones and conglomerates, except for the Heimarros and Ksiropotamos streams, where the runoff coefficient is higher in places running into loose sediments. Similarly, all of the streams coming from Askion Mountain have a low runoff coefficient (less than 10\%) in the region of the talus cones and conglomerates, except for the Ligotypos and Lagorema streams, where the runoff coefficient is higher at places outside the lignite fields, presenting values in the order of $10-20 \%$.

Taking all of the findings together, areas where the application of hydraulic protection was imperative, were identified (Figure $4 \mathrm{~b}$ ). Subsequently, hydraulic protection measures were defined and dimensioned. Finally, the design peak flow was estimated using the rational method [24], while for the mean rainfall intensity, the approved Flood Risk Management Plan of the West Macedonia River Basin District was adopted (EL 09) [25]. Indicative computations are presented in Table 1, and are compared to the calculations performed based on previous hydraulic studies' assumptions of the surface runoff value for the same area. The results indicate a reduction in the critical depth of flow by approximately $40 \%$ compared to previous hydraulic studies. 


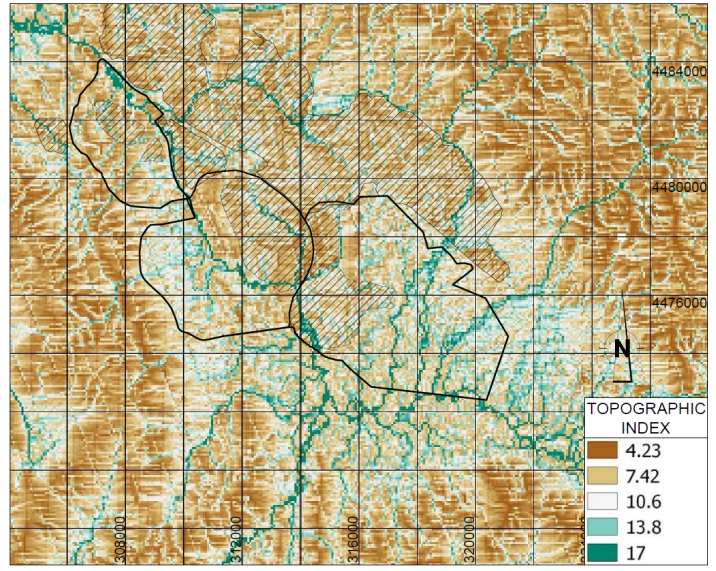

(a)

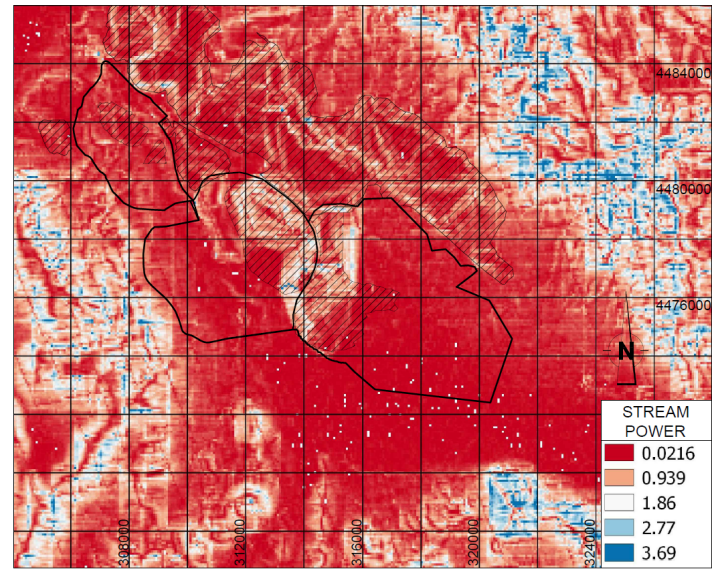

(b)

Figure 2. Spatial distribution of the topographic indices using DEM (Copernicus archive): (a) TWI, where the potential drainage networks are shown in green; (b) SI, where the potential runoff velocity is presented in blue.

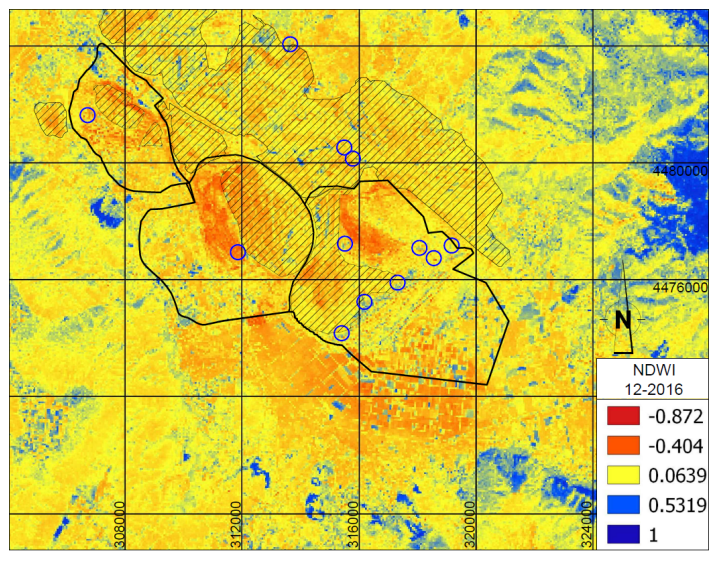

(a)

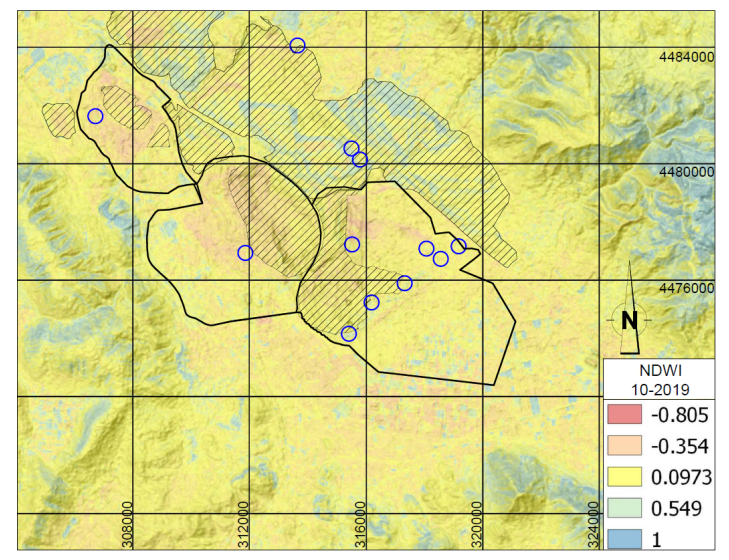

(b)

Figure 3. Spatial distribution of the spectral indices of NDWI using Sentinel-2 Satellite Imagery: (a) image acquired in December 2016; (b) image acquired in October 2019. The mine sumps are indicated with circles, and the water bodies are shown in blue.

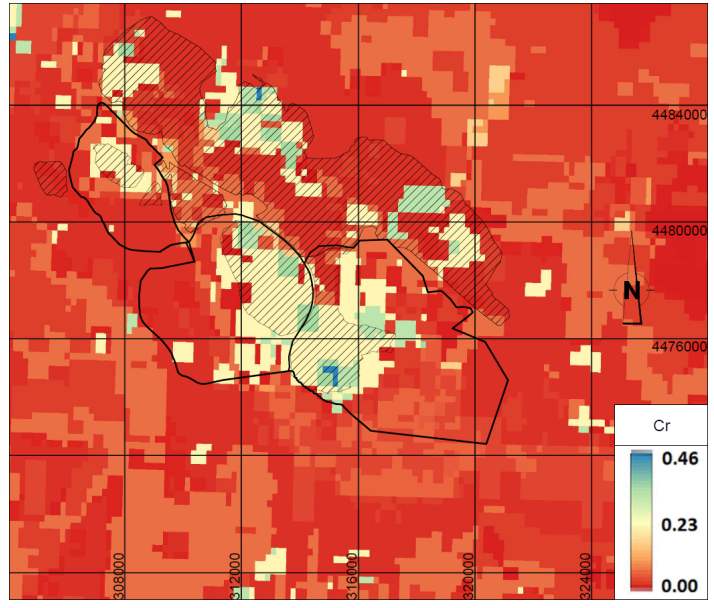

(a)

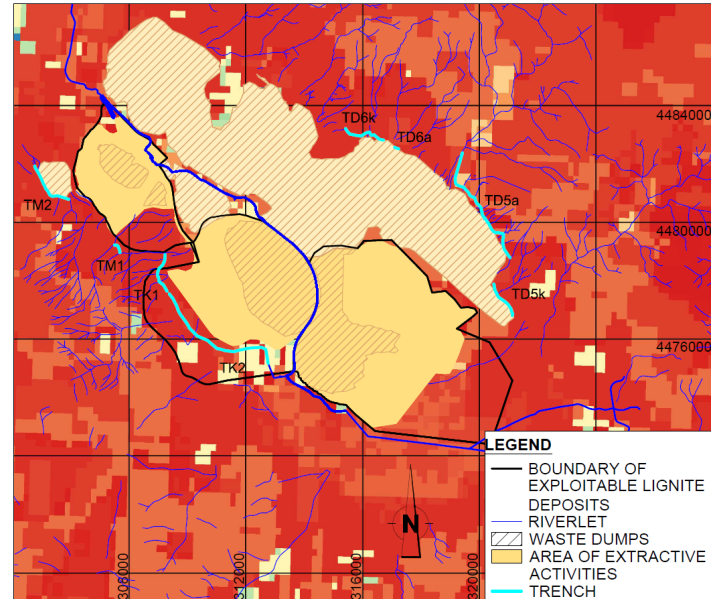

(b)

Figure 4. (a) Spatial distribution of the $C r$ values using the $C N$ European raster file; (b) the hydraulic protection measures studied. 
Table 1. Trench dimensioning.

\begin{tabular}{|c|c|c|c|c|c|c|c|}
\hline Case & Trench ID & $\begin{array}{c}\text { Runoff } \\
\text { Coefficient } \\
(\%)\end{array}$ & $\begin{array}{c}\text { Peak Flow } \\
\left(\mathrm{m}^{3} / \mathrm{s}\right)\end{array}$ & $\begin{array}{l}\text { Depth of } \\
\text { Flow (m) }\end{array}$ & $\begin{array}{c}\text { Critical } \\
\text { Depth, (m) }\end{array}$ & Froude No. & $\begin{array}{l}\text { Subsection } \\
\text { Depth (m) }\end{array}$ \\
\hline $\mathrm{i}^{1}$ & TD5 & 10 & 18.40 & 3.10 & 1.77 & 0.43 & $3.44 \sim 3.78$ \\
\hline ii $^{2}$ & TD5 & 5 & 9.20 & 1.77 & 1.11 & 0.50 & $1.97 \sim 2.17$ \\
\hline
\end{tabular}

${ }^{1}$ Calculations according to previous hydraulic studies' assumptions. ${ }^{2}$ Calculations based on the current design.

\section{Conclusions}

The changing environment in the South Ptolemais basin —with active mining areas, the rapid closure of coal mines in progress, rehabilitation plans and post-mining repurposing scenarios-is rather challenging to inspect without modern monitoring techniques. Satellite images and DEM processing provide a powerful tool for hydraulic protection and hazard assessment. In this research, several effective topography indices and satellite image processing indices were selected in order to examine the hydrological condition of the area under investigation.

The results from the analyses indicated the areas where the application of hydraulic protection was imperative. Subsequently, using remotely sensed data from satellites, a more reasonable runoff coefficient was estimated to dimension the open channels and diversion ditches. Thus, the findings of this research contribute to the growing evidence that the use of remotely sensed data could become an effective technique for the delineation of saturated and unsaturated areas, and the facilitation of decisions regarding hydraulic protection, especially in large areas with changing environments.

Author Contributions: Conceptualisation, G.L. and C.R.; methodology, G.L., C.R. and E.M.; software, G.L., C.R. and E.M.; validation, G.L., C.R., E.M., F.P. and G.K.; formal analysis, G.L., C.R., E.M., F.P. and G.K.; investigation, G.L., C.R., E.M., F.P. and G.K.; resources, G.L., C.R., E.M., F.P. and G.K.; data curation, G.L., C.R. and E.M.; writing-original draft preparation, G.L., C.R. and E.M.; writing-review and editing, G.L., C.R., F.P. and E.M.; visualisation, G.L. and C.R.; supervision, G.L. and C.R.; project administration G.L. and C.R. All authors have read and agreed to the published version of the manuscript.

Funding: This research received no external funding.

Institutional Review Board Statement: Not applicable.

Informed Consent Statement: Not applicable.

Data Availability Statement: The data presented in this study are available on request from the corresponding author.

Conflicts of Interest: The authors declare no conflict of interest.

\section{References}

1. European Commission. The European Green Deal COM(2019) 640 Final; Document EUR-Lex-52019DC0640; European Commission, Publications Office of the European Union: Brussels, Belgium, 2019.

2. European Commission. A Clean Planet for All A European Strategic Long-Term Vision for a Prosperous, Modern, Competitive and Climate Neutral Economy COM(2018) 773 Final; Document EUR-Lex-52018DC0773; European Commission, Publications Office of the European Union: Brussels, Belgium, 2018.

3. Pavloudakis, F.; Roumpos, C.; Karlopoulos, E.; Koukouzas, N. Sustainable Rehabilitation of Surface Coal Mining Areas: The Case of Greek Lignite Mines. Energies 2020, 13, 3995. [CrossRef]

4. Roumpos, C.; Sideri, D.; Pavloudakis, F.; Kolovos, N.; Michalakopoulos, T.; Apostolopoulos, G.; Galetakis, M.; Vafidis, A. Possibilities for Improving Work Efficiency of Continuous Surface Mining Systems Operating in Rocks with Excessive Digging Resistance. Górnictwo Odkryw. 2018, 59, 31-41.

5. Koukouzas, N.; Ward, C.R.; Li, Z. Mineralogy of Lignites and Associated Strata in the Mavropigi Field of the Ptolemais Basin, Northern Greece. Int. J. Coal Geol. 2010, 81, 182-190. [CrossRef] 
6. Dimitrakopoulos, D.; Koumantakis, J. Hydrogeological Conditions in Amynteon Open Lignite Mine and Design of Dewatering Measures. In Proceedings of the Proc, IMWA 2008-10th International Mine Water Association Congress; Rapantova, N., Hrkal, Z., Eds.; VSB-Technical University of Ostrava: Ostrava, Czech Republic, 2008; pp. 421-424.

7. Papakōnstantinu, A. Die Hydrogeologischen Verhältnisse im Raum der Ptolemais-Senke und des Westlichen Vermiongebirges in Griechisch-Mazedonien. Ph.D. Thesis, Freie Universität Berlin, Berlin Reimer, Germany, 1979.

8. Louloudis, G.; Mertiri, E.; Liakoura, A.; Kasfikis, G. Hydraulic Protection Works of Ptolemaida Mines from Surface Waters; PPC SA, Sector of Hydrogeological Studies: Athens, Greece, 2020; Unpublished Study of PPC SA. (In Greek)

9. Beven, K.J.; Kirkby, M.J. A Physically Based, Variable Contributing Area Model of Basin Hydrology/Un Modèle à Base Physique de Zone d'appel Variable de l'hydrologie Du Bassin Versant. Hydrol. Sci. Bull. 1979, 24, 43-69. [CrossRef]

10. Moore, I.D.; Grayson, R.B.; Ladson, A.R. Digital Terrain Modelling: A Review of Hydrological, Geomorphological, and Biological Applications. Hydrol. Process. 1991, 5, 3-30. [CrossRef]

11. Moore, I.D.; Wilson, J.P. Length-Slope Factors for the Revised Universal Soil Loss Equation: Simplified Method of Estimation. J. Soil Water Conserv. 1992, 47, 423-428.

12. Moore, I.D.; Burch, G.J. Physical Basis of the Length-Slope Factor in the Universal Soil Loss Equation. Soil Sci. Soc. Am. J. 1986, 50, 1294-1298. [CrossRef]

13. Rouse, J.W.; Haas, R.H.; Schell, J.A.; Deering, D.W.; Harlan, J.C. Monitoring the Vernal Advancement and Retrogradation (Green Wave Effect) of Natural Vegetation; NASA-CR-144661/NASA-NTRS-19750020419; NASA Goddard Space Flight Centre: Greenbelt, MD, USA, 1974.

14. Szabó, S.; Gácsi, Z.; Balázs, B. Specific Features of NDVI, NDWI and MNDWI as Reflected in Land Cover Categories. Landsc. Environ. 2016, 10, 194-202. [CrossRef]

15. Gao, B. NDWI-A Normalised Difference Water Index for Remote Sensing of Vegetation Liquid Water from Space. Remote Sens. Environ. 1996, 58, 257-266. [CrossRef]

16. McFeeters, S.K. The Use of the Normalized Difference Water Index (NDWI) in the Delineation of Open Water Features. Int. J. Remote Sens. 1996, 17, 1425-1432. [CrossRef]

17. McFeeters, S. Using the Normalized Difference Water Index (NDWI) within a Geographic Information System to Detect Swimming Pools for Mosquito Abatement: A Practical Approach. Remote Sens. 2013, 5, 3544-3561. [CrossRef]

18. $\mathrm{Xu}, \mathrm{H}$. A Study on Information Extraction of Water Body with the Modified Normalized Difference Water Index (MNDWI). J. Remote Sens. 2005, 9, 589-595.

19. Xu, H. Modification of Normalised Difference Water Index (NDWI) to Enhance Open Water Features in Remotely Sensed Imagery. Int. J. Remote Sens. 2006, 27, 3025-3033. [CrossRef]

20. Kim, N.; Shin, M.-J. Estimation of Peak Flow in Ungauged Catchments Using the Relationship between Runoff Coefficient and Curve Number. Water 2018, 10, 1669. [CrossRef]

21. McCuen, R.H.; Bondelid, T.R. Relation Between Curve Number and Runoff Coefficient. J. Irrig. Drain. Div. 1981, 107, 395-400. [CrossRef]

22. Giandotti, M. Previsione delle piene e delle magre dei corsi d'acqua. In Memorie e Studi Idrografici; Ministero dei LL.PP.; Servizio Idrografico Italiano: Rome, Germany, 1934; Volume 8, pp. 107-117.

23. Panagos, P.; Van Liedekerke, M.; Jones, A.; Montanarella, L. European Soil Data Centre: Response to European Policy Support and Public Data Requirements. Land Use Policy 2012, 29, 329-338. [CrossRef]

24. Chow, V.T. Design of Channels for Uniform Flow. In Open-Channel Hydraulics; McGraw Hill: New York, NY, USA, 1959; ISBN 07-010776-9.

25. Approval of Flood Risk Management Plan of the West Macedonia River Basin District (EL 09). Government Gazette 2689/B/6.07.2018; R09_P02; National Printing House of Greece: Athens, Greece, 2018. 